\title{
In Quest of a New AR Technology Application to Enhance the Sustainability of Cultural Tourism: The Olive Heritage in Madeira Through the Looking Glass of a 'Sandbox' Approach
}

https://doi.org/10.2478/ejthr-2021-0007

received July 14, 2020; accepted December 14, 2021

\begin{abstract}
This article presents the results of an exploratory investigation looking for new applications of augmented reality (AR) technology to enhance the sustainability of cultural tourism. The 'sandbox' approach was initially developed by programmers to experiment innovative solutions in safe conditions, being adopted later in other research areas for the same reason. In this case, the olive heritage at Madeira had been chosen as a background not because it is harmless, but on the contrary, for offering some challenging characteristics. The purpose is to stimulate creativity, forcing thought outside the box. This methodological path will lead to a new conceptthe hyperplace of augmented visit (HAV)-conciliating several kinds of attractions in a sustainable way. The general idea is to create a hybrid tour. The user will have the possibility of interacting with a mixture of real objects and digital avatars, virtually reachable by the mediation of AR. The former will be found at the location where the user stands, and the others will be distributed in different areas of the same destination. The study leads to the conclusion that this concept will encourage travellers to spend more time in each spot and to include new points of interest, less popular or even unexplored, in their itinerary, and is also resilient in a context of public health crisis. At the close, HAV's potential will be evaluated and relevant issues mapped to design a suitable working plan to implement a pilot experience.
\end{abstract}

Keywords: Cultural tourism; Sustainability; Augmented reality technology; Augmented mobility; Hyperplace of augmented visit; Olive heritage of Madeira

*Corresponding author: António José Marques da Silva, CITUR, University of Madeira, Campus of Penteada, Funchal, Portugal, ORCID: 0000-0002-5971-1574, Email: antonio.jmsilva@staff.uma.pt

\section{Introduction}

Recently, Zurab Pololikashvili predicted that sustainability will be the 'new normal' for every segment of the tourism sector in the postpandemic era. ${ }^{1}$ This statement of the United Nations World Tourism Organization Secretary General reflects the concerns a growing number of holidaymakers have with their ecological footprint. More and more, they are also looking for a technology-empowered experience (Neuhofer et al., 2014, pp. 347-348). This article will reveal the potential of a practical application of augmented reality (AR) in the field of cultural tourism, which responds to both demands. It presents the results of a preliminary investigation that explores how this technology could enhance the sustainability of attractions rooted in local heritage, in harmony with the principles of slow travel and tourism. A 'sandbox' will be assembled to achieve this goal, based on the case study of the olive tree and related products in Madeira. This kind of approach has been adopted in previous works in the field of social sciences to boost the formulation of new ideas in a protected environment. In this specific case, the food legacy chosen as the starting point of the reflection is intentionally far from being harmless. On the contrary, it presents several demanding particularities. The purpose of deliberate constraints on the design process is to induce innovative solutions, resilient even in adverse conditions. First, collecting historical data will make it possible to better understand how the peculiarities of the olive heritage in Madeira hinder the creation of a tourism experience based on related tangible elements from this autonomous region of Portugal (RAM). The challenges that must be overcome will be identified to lead to a new concept-the hyperplace of augmented visit (HAV). It will conciliate several kinds of attractions in a sustainable way. At the close, the viability

1 See https://www.unwto.org/covid-19-oneplanet-responsible-recovery. 
of this innovative model will be evaluated, and relevant issues mapped to design a suitable working plan to implement HAV.

\section{Literature Review}

AR has been one of the most exciting advances in the area of graphic computing in the last 20 years. From the invention of visual inertial odometry (Pangilinan et al., 2019, p. 78) to Pokémon mania (Serino et al., 2016), the progress has been staggering. The number of AR applications has exploded since their appearance, not only in game development, but also for industry, construction, maintenance, medicine, navigation, television, advertising, commerce, and so on (Arnaldi et al., 2018; Schmalstieg \& Höllerer 2016). In turn, almost everybody heard about AR without knowing exactly what it meant. The definition proposed by Azuma (1997) is retained here, considering only technologies that meet three basic conditions: '1. Combines real and virtual; 2. Interactive in real time; 3. Registered in 3D.' It must be constituted of at least three components (Craig, 2013, p. 40): (1) sensor(s), (2) processor, and (3) display. The display creates the illusion of intertwining between digital artefacts and the physical world. It is driven by a processor, governing the meshing between both environments, fed by data acquired by sensors. The pioneer systems depended on static hardware developed specifically for this purpose (Carmigniani \& Furht, 2011, p. 4). Wearable computers came next (Jhajharia et al., 2014). Being portable, this new generation of equipment opened the door to mobile augmented reality (MAR; Craig, 2013, pp. 209-219). Handheld devices, such as tablet PCs and mainly smartphones, are now preferred by end users, despite their many limitations (Krevelen \& Poelman, 2010; Kyselaa \& Štorková, 2015, p. 928; Olsson et al., 2013). The widespread dissemination of MAR allowed the democratization of the AR applications without any additional costs for both providers and consumers, with most of them already owning the necessary hardware (Craig, 2013, p. 213).

Despite a certain resistance against innovation (Ronchini, 2019), museums, historical monuments, and archaeological sites are surrendering to this technology (Aitamurto et al., 2018; Baker et al., 2017; Jomsri, 2019), and particularly to MAR (Avci, 2019, p. 216), as well as virtual reality and, lately, mixed reality (Bae et al., 2020). Previous research demonstrated that visitors are, in general, receptive to this new kind of experience (Aitamurto et al., 2018; Cranmer et al., 2016; Haugstvedt \& Krogstie, 2012), even if the cultural background of the user is a significant factor (Lee et al., 2015).

The interest in this tool by tourism studies is growing fast, too. More than 400 papers dedicated to this subject have been indexed by the SCOPUS database in the last 15 years, most of them related to mobile devices (Moro et al., 2019). Therefore, scholars looked into the extent to which AR could enhance the sustainability of this industry (Dewailly, 2007), a longtime concern of this research area (Hall et al., 2015). The positive and negative impacts of AR application in tourism have been highlighted by further works (Barrado-Timón \& Hidalgo-Giralt, 2019). The idea of sustainability as first presented by the Brundtland Report of the World Commission on Environment and Development (1987) was mostly about the carbon footprint of human activity (Rutty et al., 2015, p. 37). This probably explains the focus of both academics and media on aircraft pollution and the resource costs of the hospitality industry (Swarbrooke, 2015, p. 356). However, the negative effects at the level of the visited place have not yet received the deserved attention in the field of tourism studies, despite being the principal issue for policymakers, stakeholders, and researchers involved in safeguarding heritage for a long time. In fact, the invention of cultural tourism in the last quarter of the 20th century was, in itself, a response to their concern with the preservation of the most popular spots, in the face of the generalization of the habit to travel abroad (Cousin, 2008, p. 47; Silva, 2016, pp. 18-19). Nonetheless, the previous work does not focus on the potential of AR to minimize the impact of this niche (Cranmer et al., 2016). This paper is an attempt to fill this gap in research.

\section{Methodology}

\subsection{What Is a 'Sandbox' Approach?}

Programmers apply 'sandbox' to a confined environment created for experimental purposes. It enables the testing of changes of software code in controlled conditions, voluntarily limiting the actions of the user (Bishop, 2003, p. 444). In recent years, the same approach has been adopted by a few researchers from other areas (e.g., di Castri \& Plaitakis, 2018), including heritage studies (Bastian \& Harvey, 2014, p. 41), permitting work in quasi-real-world conditions (Mateo-Babiano \& Palipane, 2020, p. 9). As programmers, these scholars often followed this path for the security it provided. The 'sandbox' here has a different purpose. The olive legacy in Madeira will be used 
as a virtual laboratory to develop an AR application that endorses the sustainability of cultural tourism. This background was not chosen because it is harmless, as is the usual case. On the contrary, it challenges the targeted objective in several ways, as explained in what follows. The goal of this methodological slant is to stimulate creativity, forcing the researcher to go beyond her or his comfort zone. The intention to oblige researchers to work with adverse scenarios can foster the creation of innovative solutions, flexible enough, yet sufficiently robust to respond to unfavourable situations.

\subsection{Procedure}

The methodology adopted to achieve this exploratory study included four stages.

\subsubsection{Collect Historical Data}

Being almost unknown in Madeira at the current time, the literature rarely mentions the olive heritage of this insular territory. The information about its history must be collected from printed sources and directly from unpublished manuscripts, also, conserved at the Regional Archives of Madeira (ARM) and the National Archives of Portugal (ANTT). The ANTT's documents were consulted online ${ }^{2}$ and the others in situ. This first task will enable a better understanding of the reasons for the invisibility of this heritage, which greatly hinders its use as a tourist attraction.

\subsubsection{Assemble a 'Sandbox'}

Tangible elements related to olive heritage that are wellsuited to being converted into a tourism attraction will be located, querying the regional database of museums $(\mathrm{RDM})^{3}$ and undertaking field work at some cultural spaces. The historical facts identified earlier will be analysed to judge to what extent the items selected are representative of this food legacy in Madeira.

The characteristics of each point of interest are also considered to evaluate whether they can all be turned into sustainable spots. The challenges faced by the design of a sightseeing experience inspired on the chosen 'sandbox' are also examined.

2 Online database of the ANTT, https://digitarq.arquivos.pt/ 3 See https://museus.madeira.gov.pt.

\subsubsection{Define a New Concept of Visit Experience}

A new concept of the visit experience will be created applying AR to avoid the issues identified earlier and to respond to the goals of the exploratory study.

\subsubsection{Evaluate the Viability and Potential}

The viability and the potential of the new concept in terms of sustainability will be evaluated, not only when applied to olive heritage as a tourism attraction. The possibility of replicating the idea proposed to other kinds of legacies sharing the same characteristics and the limitations of the approach adopted will also be considered.

\section{Findings}

\subsection{Historical Inquiry}

Numerous documents belonging to the ARM and ANTT collections refer to the commerce and consumption of olives in Madeira-in the form of oil (azeite) or unprocessed (azeitona) - and even sometimes to the acclimation of the tree (oliveira) in this territory. Only a few of these sources had been published until now, which explains the current lack of historical knowledge about this subject.

\subsubsection{Acclimation}

Gaspar Frutuoso, an author of the Renaissance, wrote that the pioneers who populated the island around 1419 had planted an olive tree at Ponta de Oliveira to mark the border between the capitanias of Machico and Funchal (Azevedo, 1873, pp. 69, 79, 103). However, the acclimation of the Olea europaea seems not to have been very successful, as the silence of historical sources about this subject in the next 300 years suggests. Forster (1777, vol. 1, p. 19), who sojourned in Funchal in 1772, referred to an attempt of the Portuguese government to introduce this species. It might be the 'wild' specimens observed by the English doctor William Gourlay (1811, p. 11), and Lieutenant-Colonel Paulo Dias de Almeida during the first quarter of the 19th century (Carita, 1982, p. 52). This Portuguese officer, born on the mainland, noted that the olives were of good quality, although rare. In 1854, it was Barral's turn to mention oliveiras growing in this insular territory. However, he seemed to be unaware that the tree had been 
on the island for centuries. Indeed, he specified that at the time he was writing, it was still only an experiment (Barral, 1854, p. 120). In 1922, the Elucidário Madeirense attested to the existence of two wild species of the Olea europaea (taxon madeirensis and baxifolia), and a third, probably imported, cultivated some years before at Porto Santo, which produced edible fruits of a small size (Silva \& Menezes, 1922, vol. II, p. 234). The other two varieties had already been identified by the naturalist Richard Lowe (1868, vol. 2, part. I, pp. 20-23) 80 years earlier.

The young specimens that can be seen today in front of hotels, restaurants, and some private houses of the island's capital are not the result of these first attempts at acclimation. They have been imported from the mainland over the past 20 years. They are just ornamental plants, not being cultivated to produce olives.

\subsubsection{Commerce}

Despite the acclimation's attempts, local production has never been enough to meet the growing needs for olive oil. The Livros de Vereações (Costa, 1998, pp. 251, 265, 286) and the Livro das Posturas ${ }^{4}$ of Funchal report the import of this vegetable fat-and sometimes the fruit itself-from the mainland, but also from Spain and the port of Marseille (Silva, 1995, vol. 2, p. 721). From the end of the 15th century and beyond, the sale of this staple was regulated by the municipality (Costa, 1995, pp. 83, 304, 306; Costa, 1998, pp. 124, 144, 157, 263, 275, 343, 387, 392, 406; Costa, 2002, pp. 46, 47, 49, 65, 67, 119, 122, 127, 157, 198), even becoming the object of a royal edict in $1521 .{ }^{5}$

The books registering ship entries at the port, on deposit today at the ANTT, record the imports of olive oil in later periods. From 1727 to 1810, these documents attest to regular arrivals of vessels loaded with this foodstuff from the mainland (Sousa, 1966, vol. I, pp. 185, 188-191, 194-195), at least one of them also transporting azeitonas (Sousa, 1966, p. 192). Azeite from another unspecified Mediterranean country is reported during the same period (Sousa, 1966, pp. 214-216), and from Canarias or Maghreb, as well (Sousa, 1966, p. 212). In the early 20th century, local journals, conserved at the ARM, often announce

4 ARM, CMFUN (Posturas), livr. 685, fol. 17, 51, 59. 5 ARM, CMFUN (Serviços Administrativos / Expediente), livr. 1395, fol. 361-361v. these two products sold by drugstores. ${ }^{6}$ Both can be found today in any supermarket of the RAM.

\subsubsection{Consumption and Other Uses}

A 1589 register of Funchal's Vereações contains the first mention of the culinary use of olive oil in Madeira, to fry fish (Costa, 2002, p. 65). It was a very popular dish during Lent in the upper strata of the colonial society, being part of the diet at the convents of the island's capital. ${ }^{7}$ Indeed, the accounting books of these institutions often refer to azeite. This vegetable oil was used as an ingredient in some delicacies, such as sonhos. ${ }^{8}$ It was, moreover, present at the refectory's table as a seasoning. ${ }^{9}$ However, it was not always acquired to be eaten. A significant amount was used by nuns for illumination..$^{10}$ We also know, thanks to a 1550 register of the Vereações, that this kind of fat was employed locally to make soap, too (Costa, 1998, p. 433).

The accounting books of Funchal's convents refer to the consumption of azeitonas, already recorded at the Convent of Encarnação in 1672, during Lent. ${ }^{11}$ Likewise, this female institution purchased olives on the occasion of celebrations to prepare filling for poultry and buckling. From the end of the 1600s at least, they were used to make empadas, too. ${ }^{12}$ These fatty fruits were bought for the same purpose by the Santa Clara community in the third quarter of the next century. ${ }^{13}$ In the years between 1820 and 1830, they were employed in the cuisine of this establishment to stuff fowl ${ }^{14}$ and kids, ${ }^{15}$ as reported in the Convent of Encarnação, and even fish. ${ }^{16}$ The small convent of Nossa Senhora das Mercês acquired azeitonas only twice. ${ }^{17}$ The other monasteries, subject to a less rigid rule, shared the food habits of their social milieu, the members having a more diverse diet (Carita, 1999, p. 332).

6 ARM, Jornais, Diário da Madeira: No. 2536 (04/09/1919), p. 2; No. 2956 (17/02/1921), p. 2; No. 2956 (17/02/1921), p. 2; No. 3230 (28/01/1922), p. 2, etc.

7 ANTT, CNSEF, livr. 41, 1820-1823, fol. 36.

8 ARM, Governo Civil (Conventos), liv. 274, 1764-1794, fol. 123. 9 ARM, Governo Civil (Conventos), liv. 274, 1764-1794, fol. 165. Idem. fol. 191v.

10 ARM, Governo Civil (Conventos), liv. 273, 1737-1758, fol. 33.

11 ARM, CNSEF (receita e despesa), livr. 14, 1669-1672, fol. 57.

12 ARM, CNSEF (receita e despesa), livr. 16, 1687-1690, fol. 20.

13 ANTT, CSCF, livr. 49, 1768-1771, fol. 33v.

14 ANTT, CSCF, livr. 58, 1826-1829, fol. 47, 48v.

15 ANTT, CSCF, livr. 68, 1829-1832, fol. 26v.

16 ANTT, CSCF, livr. 79, 1873-1876, fol. 78.

17 ARM, Governo Civil (Conventos), liv. 274, 1764-1794, fol. 172. Idem, fol. 177v. 
In the first half of the twentieth century, the consumption of olive oil was no longer the exclusive privilege of the richest. It was used to fry several popular delicacies and to season soups (Pereira, 1939/1989, vol. 2, pp. 574, 579, 581, 582, 585; Cruz, 1949/1963, pp. 42, 43, 46, 47). Furthermore, the fruit itself was now appreciated as an ingredient of a sophisticated dish, the cuscus rico (Cruz, 1949/1963, p. 43), and to stuff buckling, too, perpetuating the habit inherited from the upper class of the modern times (Pereira, 1939/1989, vol. 2, p. 583). Currently, despite the lack of local production, a recent study (Lopes et al., 2017, p. 181) revealed that each inhabitant of Madeira consumes an average amount of $7.8 \mathrm{~g}$ of azeite daily, it being clearly preferred to other vegetable oils ( $1.6 \mathrm{~g} /$ day).

\subsubsection{Lessons Learned}

Whether there were several attempts to acclimate olive trees in Madeira over time or not, they were never very successful for reasons that remain to be studied. In contrast, the import of azeite was recorded since the 15th century, and it remains constant today. The subject is not well known, but there are many documents mentioning this product in the collections of the regional and national archives. The consumption of this vegetable fat and the fruit in its raw state is still significant. Although both belong to the insular food system, being omnipresent in the longue duree, the valuing of its cultural importance is currently practically zero. The recent attempt to promote Madeiran cuisine as being representative of the Mediterranean model (Almeida \& Garrod, 2017, p. 175) has not yet improved the perception of olive oil as a basis of the local diet. For a very long time, indeed, azeite and azeitona have been on the plate of the islanders. However, Madeirans do not value this product as a culinary legacy, which greatly hinders the task of assembling a 'sandbox' based on this kind of heritage.

\subsection{Assembling the 'Sandbox'}

The field work in several cultural spaces of Madeira and the RDM's queries resulted in the identification of only four potential spots related to olive heritage.

\subsubsection{Museu Quinta das Cruzes}

Located in the Funchal parish of São Pedro, this museum (HVA 1) was the most visited in the RAM between January and April 2016 (15,017 of 40,000 total entries). ${ }^{18}$ The temporary closing in 2018 contributed significantly to the global decrease of $-19.6 \%$ registered the same year in all facilities of this kind run by the regional government. ${ }^{19}$ It was founded in 1953, occupying a traditional quinta, which houses several private collections. It is dedicated to the evolution of decorative arts and the history of Madeira (Sousa, 2015). The ceramics are particularly well represented, totalling around 700 pieces of faience and porcelain, covering different periods. ${ }^{20}$

A query in the DRM enabled the identification of three sets of 19th-century earthenware (MQC 1119, MQC 1128, MQC 1470), which, in terms of typology, belong to the category of cruet called galheteiro in Portuguese (Figure 1). These decorated vessels, imported from the mainland, were used in well-off houses to bring olive oil, vinegar, and sometimes salt and mustard to the dining table.

\subsubsection{Museu Etnográfico da Madeira}

The Museu Etnográfico da Madeira (HVA 2) was installed in an old building in Ribeira Brava, a little coastal town about $20 \mathrm{~km}$ from Funchal. It opened in 1996 to house the ethnographic collections of the Regional Directorate of Cultural Affairs. Twenty years later, it was the second most frequented museum after the Museu da Quinta das Cruzes between January and April 2016 (9,202 of 40,000 total entries). However, many of the visitors were autochthonous and not tourists. ${ }^{21}$

Different aspects of the RAM's socioeconomic life are staged in the exhibition rooms: fishing, domestic spaces, transport, cereal processing, viticulture, and commerce. ${ }^{22}$ A query in the RDM identified just one 20th-century dispenser. This kind of instrument was used to control the quantity of olive oil sold in the traditional drugstores (vendas) of the island (ref. 97/1324; Figure 1).

18 See https://viagens.sapo.pt/viajar/viajar-portugal/artigos/maisde-40-mil-visitaram-museus-da-madeira-nos-primeiros-quatro-meses-do-ano.

19 See https://estatistica.madeira.gov.pt/download-now/social/ cultura-desporto-lazer-pt/cultura-noticias-pt/2273-04-12-2019-em2018-os-museus-da-ram-tiveram-menos-visitantes-enquanto-cinemas-e-espetaculos-ao-vivo-tambem-registaram-quebras-nos-espetadores-despesa.

20 See https://mqc.madeira.gov.pt/.

21 Cf. Note 18

22 See http://www.visitmadeira.pt/pt-pt/o-que-fazer/cultura/ pesquisa/museu-etnografico-da-madeira. 

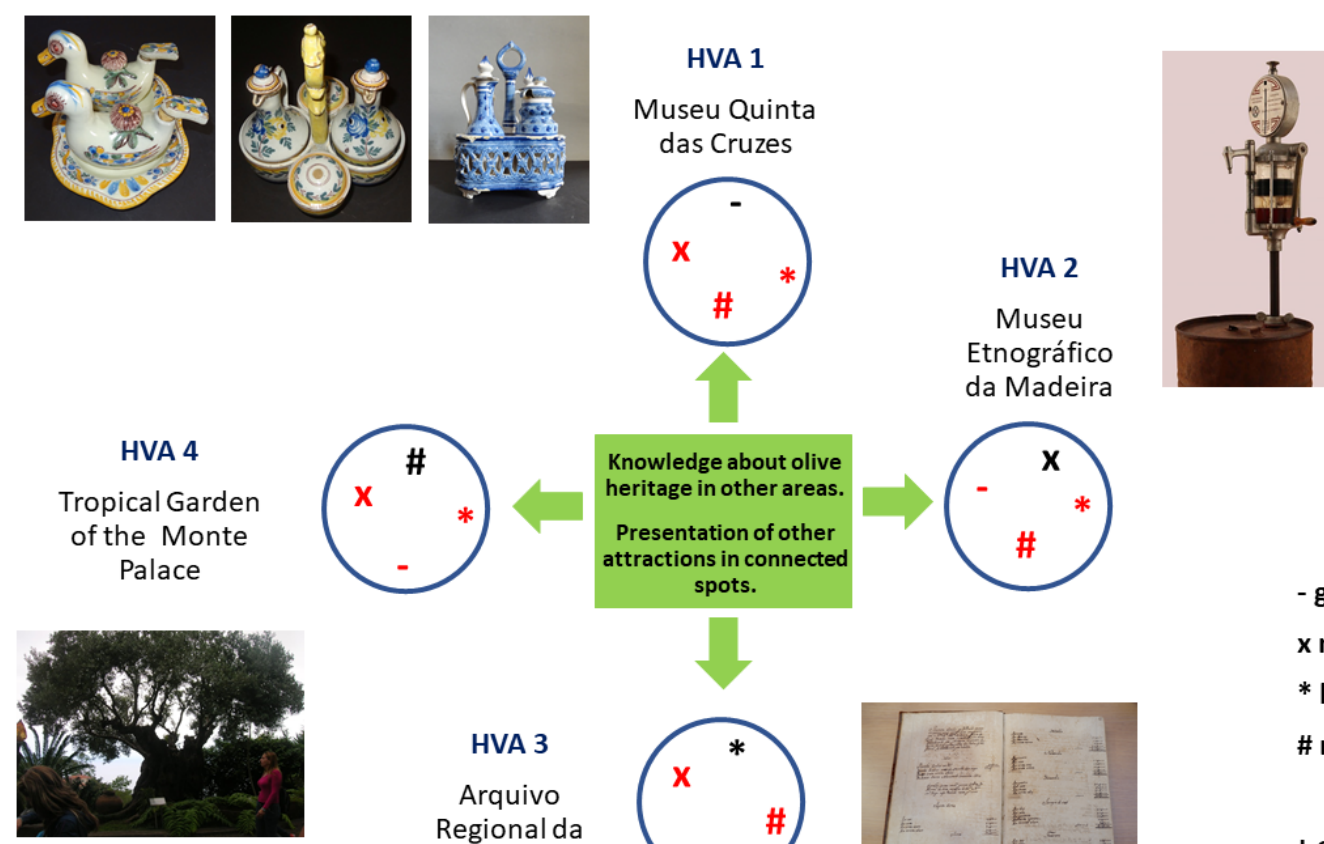

- galheteiros

$\mathbf{x}$ medidor

* historical documents

\# millenary olive trees

HVA 3
Arquivo
Regional da
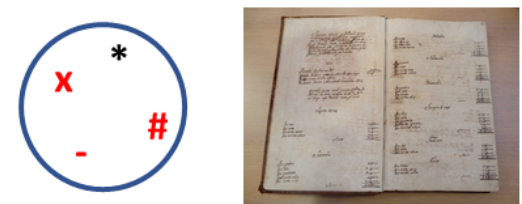

+ carrying attractions

+ connected attractions

Figure 1: The 'sandbox' assembled, applying the HVA concept to the case study of the olive heritage in Madeira.

\subsubsection{Regional Archives of Madeira (ARM)}

The ARM (HVA 3) inherited the historical documents belonging to the District Archives (Arquivo Distrital) of Funchal, founded in 1931, which was enriched by other collections in recent decades. ${ }^{23}$ Since 2004, the ARM has been installed in a modern building, shared with the Regional Library. The ground floor is set up to host temporary exhibitions, offering the possibility of guided visits. However, the principal users of this service are local student, not tourists. The Funchal neighbourhood where this building is located (Álamos) has no popular spots and is totally ignored by holidaymakers.

As mentioned earlier, the ARM holds numerous historical documents and some old books referring to imports, consumption, and the acclimation of Olea europaea in Madeira (Figure 1).

\subsubsection{Monte Palace Tropical Garden}

Monte Palace (HVA 4) is a bicentenary quinta, converted later into the Palace Hotel. It is located at Monte, a Funchal parish frequented by numerous tourists, being directly connected to the historical centre by a cable car service.

23 See https://abm.madeira.gov.pt/.
The garden of the property, which belongs today to the Joe Berardo Foundation, hosts an eclectic mix of plants, minerals, artefacts, and outdoor art from the island and other regions of the world. ${ }^{24}$ No official visitor statistics are available. However, it is the seventh-ranked activity of the 159 currently ranked in the city by the portal Trip Advisor, rated excellent by most of the 8,392 travellers who took part in the evaluation process. ${ }^{25}$

We can see three millenary olive trees in two different areas of the quinta (Figure 1). An information panel located near one of them tells their history. They were planted 1,700 years ago in the region of Alqueva (Alentejo, southeast Portugal) by Romans. The old oliveiras were rescued by the Joe Berardo Foundation within the framework of the construction of a dam in the 1990s, to be acclimated in its property.

\subsection{Challenges to Overcome}

As the olive heritage is not valued as an identity marker by Madeirans, the few tangible elements related to this

24 See http://www.visitmadeira.pt/pt-pt/explorar/detalhe/quinta-monte-palace.

25 See https://www.tripadvisor.pt/ShowUserReviews-g189167d196135-r581630281-Monte_Palace_Madeira-Funchal_Madeira_Madeira_Islands.html. 
legacy are dispersed in a diversified set of places. The limited 'sandbox' assembled by the force of necessity includes only two museums, an open-door attraction, and the ARM, the last one not integrated into tourist circuits. The fact that the Museu da Ribeira Brava is $20 \mathrm{~km}$ away from Funchal can explain why only a few travellers visit this cultural space. The other potential spots have the advantage of being easily accessible from the Lido, the hotel district of Funchal. It is well known that museums have an important role in maintaining what Walsh (2002, pp. 148-159) called the sense of place and in building the local identity. Indeed, from the outset, they are considered to be prime pedagogical instruments (Smith, 2006, p. 198). In this particular instance, artefacts related to the consumption and culture of oliveira are notably invisible due to the ignorance of the island's inhabitants about this legacy. The same happens with the museum staff. Witha few exceptions (Chevallier, 2008, p. 634; cf. the case study of olive oil), the collecting methodologies adopted in this arena tend to privilege tangible elements from the areas of production instead of documenting the widespread circulation of foodstuffs from distant regions. In turn, the public still conceives of exhibitions as a staging of the 'truth', as argued by Hollinshead (1997). However, there is often a certain delay between the current state of the art about a subject in the academic milieu and the 'cultural representations' based on it (Salazar, 2009, p. 51). As the history of the olive in Madeira has not been written yet, and the tree is not cultivated locally for its fruit today, the objects related to this heritage are rare at the Museu da Quinta das Cruzes and the Museu Etnográfico da Madeira. In both museums, the minimum number of artefacts required to prepare an exhibition on this subject is far from being reached.

Focusing on a logic of systematic sampling, the ARM, on the other hand, safeguards numerous manuscripts and out-of-print books referring to azeite and azeitonas. However, making a collection of archived documents a crowd attraction is a challenge in itself, despite the potentialities (Moiteiro, 2016).

The improbable presence of millenary olive trees at the Monte Palace is the result of the nonconventional strategy of acquisitions implemented by the Joe Berardo Foundation in recent decades. The abundance and diversity of attractions surrounding the majestic oliveiras keeps travellers from giving them the attention they deserve.

In light of all these facts, the 'sandbox' assembled is far from being an easy and safe background of conceptual development. On the contrary, it presents several particularities, which make a normal sightseeing experience difficult, even without taking into account concerns for sustainability. In practice, the solution proposed must overcome the scarcity and reduced visibility of tangible elements related to the olive heritage in almost all the potential spots identified. Moreover, one of them (HVA3) is not actually considered an attraction by tourists and another (HAV4) is located outdoors.

\subsection{A New Concept: Hyperplace of Augmented Visit}

Hyperplace of augmented visit is a neologism based on the concept of 'hyperplace', in the sense given to this term by geographer Michel Lussault (2017). It means a halfreal/half-virtual exhibition that provides the framework for a new kind of experience. This hybrid tour makes it possible to understand the richness of a cultural heritage by making contact with a combination of objects visible at this location (carrying attractions [CAA]) and those that are computer-reproduced (connected attractions [COA]), crossing information from several spaces, more or less distant. This can result in a telescoping between different levels of the data characteristic of hyperplaces (local, regional, national, and global), the so-called hyperscalarity. Each CAA acts as a portal to a ubiquitous sightseeing environment experienced by all users independent of where they stand, the whole being more than the sum of carrying and connected parts.

\subsection{Applying the HVA's Concept to the 'Sandbox'}

In practice, the AR will make it possible to offer a visit experience that integrates the CAA found at each of the potential spots presented here with the COAs belonging to the others (Figure 1).

It is an efficient way to amplify the visitor's perception of the tangible elements related to this kind of cultural legacy in a single HVA. It enables the minimization of the issue mentioned earlier of the scarcity of artefacts available at each of the four potential spots. The use of AR technology will also make it possible to transmit general information about:

1. The history of the olive in Madeira and other Portuguese territories, and various other parts of the world.

2. The cultural spaces, where the COA are located, and where they are from, in the specific case of the millenary trees imported from the mainland. 
The connectedness induced by AR between the four attractions will take advantage of the popularity of the Monte Palace. The idea is to give visibility to the two museums, less frequented than the garden of this property and the ARM, too, which is totally out of the tourism circuit. The ultimate goal is to motivate travellers to discover on their own the other collections exhibited in each location. Moreover, the users of this outdoor space will have the possibility to observe cultural elements normally available only inside the buildings, which ensures the conditions necessary to guarantee their physical integrity. Taking place outside walls, this hybrid sightseeing is not only sustainable-as explained later-but also resilient to pandemic events, configuring a safer experience in regard to concerns about the risks of viral transmission (Contini \& Costabile, 2020). From this point of view, the HVA concept enables an effective response to the challenges of the 'sandbox' assembled, and even more. We will see next to what extent the solution proposed can significantly enhance the sustainability of cultural tourism.

\section{Discussion}

First, the implementation of the HVA concept could lead tourists to spend more time at the places they visit, giving them the opportunity to discover new spots and access to others that were not necessarily part of their plans. It also could help to reestablish the balance between cultural and natural attractions, more fragile and usually more sought out by holidaymakers sojourning in Madeira (Oliveira \& Pereira, 2008, p. 166).

As HVA 1, 2, and 3 will be installed in points of interest often listed in travel guides, individuals who initially were not looking for technology-based experiences or for olive heritage information will be confronted with a conjugation of both without having to seek them out. Back in their countries of origin, they can be ambassadors for this complementary dimension of the destination. Nevertheless, the regional archives, hitherto deemed not appealing to holidaymakers, gain an unprecedented functionality.

If it becomes very successful, the HVA model applied to other kinds of legacies could make it possible to rationalize visitor flows, increasing the variety of activities offered by the most frequented places without increasing the negative impacts on their surroundings. Enhancing their attractiveness with AR can also trigger the desire to come back, as pointed out by Özkul and Kumlu (2019, p. 111) in regard to the case study of the Cleveland Museum of Art.
Staying longer in the same place means holidaymakers reduce their carbon footprint. From this point of view, the HVA concept is in harmony with the environmental awareness espoused by slow travel and tourism (Dickinson \& Lumsdon, 2010, p. 90; Fullagar et al., 2012). The potential of HVA to make heritage, underrated by host communities, more visible also contributes to diversifying the offerings. In the end, it will leverage the time spent at a destination.

The HVA model could also reduce the ecological impact on the most popular places, channelling traffic to alternative attractions that have been ignored to date. There is also the possibility of implementing HVAs in facilities usually frequented by holidaymakers (airports, train stations, hotels, etc.), making this visit experience pervasive throughout all stages of a trip. Considering the limited cost of putting a single CAA in each spot selected, it would be an inexpensive way to introduce travellers to attractions they did not plan to look for. On the other hand, museums and any other space with small collections could take advantage of this new AR application to upgrade their offerings. In marginalized areas, local craftsmen, farmers, or even food producers could collaborate with institutions in this field on joint HVA projects. Exploring shared legacies together, they could compete with more popular destinations, completing the sightseeing with related intangible experiences, such as master classes, community-based activities, and more.

Another potential of this new visit model is particularly relevant in the context of the COVID-19 crisis and even future pandemic waves: increasing the scope of outdoor tours, mobilizing artefacts only previously available inside buildings. It would make it possible to avoid the concentration of individuals in closed spaces presenting a higher risk of viral contamination. In turn, it will give museums a chance to maintain the link with a larger public when their access is restricted for health reasons.

Even if it seems promising, the impacts and the outcome of HVA need to be tested extensively in the field to confirm whether the concept lives up to expectations. Complementary research should be undertaken first to conceive a convenient and affordable system of sensor-processor-display, including hardware and software adequate to the four spots selected. The fact that one of them is outdoors (HV4) should be taken into account. The possibility of installing HVAs in other kinds of spaces frequented by tourists (restaurants, hotels, airports, etc.) should also be considered. The implementation stage will require satisfaction surveys and the monitoring of the effective benefits for the environment. 


\section{Conclusions}

Some scholars believe that the future of tourism depends on a successful match between sustainability and resilience (Lew, 2020; Romagosa, 2020; Salazar, 2020), in which innovation will play an important role (Lew \& Cheer, 2018, pp. 320-21). The 'sandbox' approach based on the olive heritage in Madeira undergirds the potential of AR to develop solutions that respond to these two goals, focusing primarily on the interaction with the attraction itself. The assemblage presented here led to a creative formula to enhance the sustainability of cultural tourism using this technology: the HAV. It encourages travellers to spend more time in each spot and to include new points of interest, less popular or even unexplored, in their itinerary. Underrated legacies can gain importance through the application of this new concept of a visit. In addition, it opens the door to several other exciting possibilities: the access to attractions that had been until now the exclusive domain of museums in alternative environments resilient to pandemics and promotion of facilities of this kind that have modest collections. Contrary to what normally happens (Ratten et al., 2020, p. 9), implementing this 'green' model favours small providers of tourism products instead of larger ones. It could give the opportunity to stakeholders, usually not involved, to join HVA projects to enrich the observation sparked by the contemplation of tangible elements with activities related to the same heritage. It also opens the door to a kind of augmented mobility, allowing visit experiences during the journey to the destination. However, more preliminary studies need to be undertaken before confirming the viability of the concept proposed. The next step will be the development of a device prototype and its implementation in the field to monitor the feedback of tourists and to evaluate to what extent the impacts and the outcomes expected can be effectively reached in a satisfying way.

\section{Acknowledgements}

The author wants to thank the CITUR-Centre for Tourism Research, Development and Innovation (Pole Madeira) for the financial funding granted to support his participation in the ITC '20 XII International Tourism Congress and the proofreading and review of this paper.

\section{Bionote}

António José Marques da Silva holds a PhD degree in history and archaeology from the University of Coimbra (2009) and took postdoctoral training in the same field (20102015). His domain of expertise includes various topics, such as the safeguarding and management of cultural heritage, digital humanities, intangible cultural heritage, museum exhibitions, food history, food ethnology, and cultural tourism. He is an integrated researcher at CITURCentre for Research, Development and Innovation in Tourism and guest professor at the ESTG (Higher School of Technologies and Management, University of Madeira). He also is a Scientific Committee member of the Cultural Foundation 'The Routes of the Olive Tree', associate expert of the PhD School 'Food Heritage, Cultures and Identities' at the University of Coimbra (FLUC), collaborator of the UNESCO Chair in Intangible Heritage and Traditional Know-How: Linking Heritage, University of Evora (CIDEHUS), and member of the international network 'Food Heritage of the Lusophony' (DIAITA).

\section{References}

[1] Aitamurto, T., Boin, J.-B., Chen, K., et al. (2018). The impact of augmented reality on art engagement: Liking, Impression of learning, and distraction. In J. Y. C. Chen \& G. Fragomeni (Eds.), Virtual, augmented and mixed reality: Applications in health, cultural heritage, and industry (pp. 153-171). Springer International.

[2] Almeida, A., \& Garrod, B. (2017). Experiences with local food in a mature tourist destination: The importance of consumers' motivations. Journal of Gastronomy and Tourism, 2(3), 173-187.

[3] Arnaldi, B., Cotin, S., Couture, N., et al. (2018). New applications. In B. Arnaldi, P. Guitton, \& G. Moreau (Eds.), Virtual reality and augmented reality: Myths and realities (pp. 1-72). Wiley.

[4] Avci, E. (2019). Enhancing the cultural tourism experience through augmented reality. In C. Cobanoglu, M. Cavusoglu, \& A. Corbaci (Eds.), Advances in global business and economics (Vol. 2, pp. 215-230). ANAHEI.

[5] Azevedo, A. R. de (1873). As saudades da terra. Typographia Funchalense.

[6] Azuma, R. T. (1997). A survey of augmented reality. Presence: Teleoperators and Virtual Environments, 6(4), 355-385.

[7] Bae, S., Jung, T. H., Moorhouse, N., et al. (2020). The influence of mixed reality on satisfaction and brand loyalty in cultural heritage attractions: A brand equity perspective. Sustainability, 12(2956). https://doi.org/10.3390/ su12072956

[8] Baker, E. J., Bakar, J. A. A., \& Zulkifli, A. N. (2017). Elements of museum mobile augmented reality for engaging hearing- 
impaired visitors. Journal of Telecommunication, Electronic and Computer Engineering, 9(2-12), 171-178.

[9] Barrado-Timón, D. A., \& Hidalgo-Giralt, C. (2019). The historic city, its transmission and perception via augmented reality and virtual reality and the use of the past as a resource for the present: A new era for urban cultural heritage and tourism? Sustainability, 11(10). http://dx.doi.org/10.3390/ su11102835.

[10] Barral, F. A. (1854). Noticia sobre o clima do Funchal e sua influencia no tratamento da tisica pulmonar. In A. J. F. Silva (Ed.), Memorias da Academia Real das Sciencias de Lisboa, Primeira Classe, Nova Série, Tomo I - Parte I (pp. 3-257). Imprensa Nacional.

[11] Bastian, J. A., \& Harvey, R. (2014). Experiments in cultural heritage informatics: Convergence and divergence. In S. K. Hastings (Ed.), Annual review of cultural heritage informatics: 2012-2013 (pp. 29-42). Rowman \& Littlefield.

[12] Bishop, M. (2003). Computer security: Art and science. Addison-Wesley Professional.

[13] Carita, R. (1982). Paulo Dias de Almeida e a descrição da Madeira de 1817-1827. Direcção Regional dos Assuntos Culturais.

[14] Carita, R. (1999). História da Madeira. O século XVIII: Economia e sociedade. Secretaria Regional da Economia.

[15] Carmigniani, J., \& Furht, B. (2011). Augmented reality: An o1verview. In B. Furht (Ed.), Handbook of augmented reality (pp. 3-46). Springer.

[16] Chevallier, D. (2008). Collecter, exposer le contemporain au MUCEM. Ethnologie française, 38(4), 631-637.

[17] Contini, D., \& Costabile, F. (2020). Does air pollution influence COVID-19 outbreaks? Atmosphere, 11(377). https:// doi.org/10.3390/atmos11040377

[18] Costa, J. P. da (1995). Vereações da Câmara Municipal do Funchal: Século XV. Centro de Estudos de História do Atlântico.

[19] Costa, J. P. da (1998). Vereações da Câmara Municipal do Funchal: Primeira metade do século XVI. Centro de Estudos de História do Atlântico.

[20] Costa, J. P. da (2002). Vereações da Câmara Municipal do Funchal: Segunda metade do século XVI. Centro de Estudos de História do Atlântico.

[21] Cousin, S. (2008). L'UNESCO et la doctrine du tourisme culturel. Généalogie d'un "bon” tourisme. Civilisations, 57(1-2), 41-56.

[22] Craig, A. B. (2013). Understanding augmented reality: Concepts and applications. Elsevier.

[23] Cranmer, E., Jung, T., tom Dieck, M. C., et al. (2016). Implementing augmented reality to increase tourist attraction sustainability. In M. C. tom Dieck \& T. Jung (Eds.), Perspectives on business realities of $A R$ and $V R$ conference, Dublin, 27/04/2016 (pp. 44-48). Manchester Metropolitan University/CARH/DIT.

[24] Cruz, V. do P. da (1963). A culinária madeirense. Das Artes e da História da Madeira, 33, 42-47. (Original work published 1949)

[25] di Castri, Simone and Plaitakis, Ariadne, Going Beyond Regulatory Sandboxes to Enable FinTech Innovation in Emerging Markets (January 23, 2018). Available at SSRN: https://ssrn.com/abstract=3059309 or http://dx.doi. org/10.2139/ssrn.3059309
[26] Dewailly, J.-M. (2007). Sustainable tourist space: From reality to virtual reality? Tourism Geographies, 1(1), 41-55.

[27] Dickinson, J., \& Lumsdon, L. (2010). Slow travel and tourism. Earthscan.

[28] Forster, G. (1777). A voyage round the world. B. White.

[29] Fullagar, S., Wilson, E., \& Markwell, K. (2012). Starting slow: Thinking through slow mobilities and experiences. In S. Fullagar, K. Markwell, \& E. Wilson (Eds.), Slow tourism experiences and mobilities (pp. 1-8). Channel Views Publications.

[30] Gourlay, W. (1811). Observations on the natural history, climate, and diseases of Madeira: During a period of eighteen years. J. Callow.

[31] Hall, C. M., Gössling, S., \& Scott, D. (2015). The evolution of sustainable development and sustainable tourism. In C. M. Hall, S. Gössling, \& D. Scott (Eds.), The Routledge handbook of tourism and sustainability (pp. 15-35). Routledge.

[32] Haugstvedt, A. C., \& Krogstie, J. (2012). Mobile augmented reality for cultural heritage: A technology acceptance s1tudy. In International Symposium on Mixed and Augmented Reality (Atlanta, 5-8 November 2012), Science and technology proceedings (pp. 247-255). IEEE.

[33] Hollinshead, K. (1997). Heritage tourism under post-modernity: Truth and the past. In C. Ryan (Ed.), The tourist experience: A new introduction (pp. 170-193). Cassell.

[34] Jhajharia, S., Pal, S. K., \& Verma, S. (2014). Wearable computing and its application. International Journal of Computer Science and Information Technologies, 5(4), 5700-5704.

[35] Jomsri, P. (2019). Creative innovation of augmented reality for promoting sustainable tourism of Chiang Mai Moat. Journal of Physics: Conference Series, 1335(012010). https://doi. org/10.1088/1742-6596/1335/1/012010

[36] Krevelen, D. W. F. van, \& Poelman, R. (2010). A survey of augmented reality technologies: Applications and limitations. International Journal of Virtual Reality, 9(2), 1-20.

[37] Kyselaa, J., \& Štorková, P. (2015). Using augmented reality as a medium for teaching history and tourism. Procedia-Social and Behavioral Sciences, 174, 926-931.

[38] Lee, H., Chung, N., \& Jung, T. (2015). Examining the cultural differences in acceptance of mobile augmented reality: Comparison of South Korea and Ireland. In I. Tussyadiah \& A. Inversini (Eds.), Information and communication technologies in tourism (pp. 477-491). Springer.

[39] [39] Lew, A. (2020, March 16). How to create a better post-COVID-19 world. Medium. https://medium.com/@ alanalew/creating-a-better-post-covid-19-world-36b2b3e8a7ae

[40] Lew, A. A., \& Cheer, J. M. (2018). Lessons learned: Globalization, change, and resilience in tourism communities. In J. M. Cheer \& A. A. Lew (Eds.), Tourism resilience and sustainability: Adapting to social, political, and economic change (pp. 319-323). Routledge.

[41] Lopes, C., Torres, D., Oliveira, A. et al. (2017). Inquérito alimentar nacional e de atividade física, IAN-AF 2015-2016: Relatório de resultados. Universidade do Porto. http://www. ian-af.up.pt

[42] Lowe, R. T. (1868). A manual flora of Madeira and the adjacent islands of Porto Santo and the Desertas (Vol. 1). John Van Voorst. 
[43] Lussault, M. (2017). Hyper-lieux : Les nouvelles géographies de la mondialisation. Média Diffusion.

[44] Mateo-Babiano, I., \& Palipane, K. (2020). Reimagining place through the sandbox studio pedagogy: An introduction. In I. Mateo-Babiano \& K. Palipane (Eds.), Placemaking sandbox: Emergent approaches, techniques and practices to create more thriving places (pp. 1-14). Springer.

[45] Moiteiro, G. C. (2016). What if documentary heritage attracted tourists? Thoughts on the potential for tourism of historical libraries and archives. In C. Henriques, M. C. Moreira, \& P. B. César (Eds.), Tourism and history, world heritage: Case studies of Ibero-American space (pp. 568-584). CICS-NOVA.

[46] Moro, S., Rita, P., Ramos, P., et al. (2019). Analysing recent augmented and virtual reality developments in tourism. Journal of Hospitality and Tourism Technology, 10(4), 571-586.

[47] Neuhofer, B., Buhalis, D., \& Ladkin, A. (2014). Typology of technology-enhanced tourism experiences. International Journal of Tourism Research, 16, 340-350.

[48] Oliveira, P., \& P. T. Pereira. (2008). Who values what in a tourism destination? The case of Madeira Island. Tourism Economics, 14(1), 155-168.

[49] Olsson, T., Lagerstam, E., Karkkainen, T., et al. (2013). Expected user experience of mobile augmented reality services: A user study in the context of shopping centres. Personal and Ubiquitous Computing, 17(2), 287-304.

[50] Özkul, E., \& Kumlu, S. T. (2019). Augmented reality applications in tourism. International Journal of Contemporary Tourism Research, 3(2), 107-122.

[51] Pangilinan, E., Lukas, S., \& Mohan, V. (2019). Creating augmented and virtual realities. O'Reilly Media.

[52] Pereira E. C. N. (1989). Ilhas do Zarco. Câmara Municipal do Funchal. (Original work published 1939)

[53] Ratten, V., Braga, V., Álvarez-García, J., et al. (2020). Tourism innovation: The role of technology, sustainability and creativity. In V. Ratten, V. Braga, J. Álvarez-García, et al. (Eds.), Tourism innovation: Technology, sustainability and creativity (pp. 31-43). Routledge.

[54] Romagosa, F. (2020). The COVID-19 crisis: Opportunities for sustainable and proximity tourism. Tourism Geographies, 22(3), 690-694.
[55] Ronchini, C. (2019). Cultural paradigm inertia and urban tourism. In E. Fayos-Solà \& C. Cooper (Eds.), The future of tourism innovation and sustainability (pp. 179-194). Springer.

[56] Rutty, M., Gössling, S., Scott, D., et al. (2015). The global effects and impacts of tourism: An overview. In C. M. Hall, S. Gössling, \& D. Scott (Eds.), The Routledge handbook of tourism and sustainability (pp. 36-163). Routledge.

[57] Salazar, N. B. (2009). Imaged or imagined? Cultural representations and the "tourismification" of peoples and places. Cahiers d'études africaines, 193-194, 49-71.

[58] Salazar, N. B. (2020). Labour migration and tourism mobilities: Time to bring sustainability into the debate. Tourism Geographies. https://doi.org/10.1080/14616688.20 20.1801827.

[59] Schmalstieg, D., \& Höllerer, T. (2016). Augmented reality: Principles and practice. Addison-Wesley.

[60] Serino, M., Cordrey, K., McLaughlin, L. et al. (2016). Pokémon Go and augmented virtual reality games: A cautionary commentary for parents and pediatricians. Current Opinion in Pediatrics, 28(5), 673-677.

[61] Silva, A. J. M. da. (2016). Diaita Nostra: Patrimoines alimentaires, identité et gouvernementalité en Méditerrannée. UNESCO Chair in Intangible Heritage and Traditional Know-How, University of Evora.

[62] Silva, F. A. da, \& Menezes, C. A. de (1922). Elucidário Madeirense. Typografia Esperança.

[63] Silva, J. M. A. e S. (1995). A Madeira e a construção do mundo atlântico (século XV-XVII). Centro de Estudos de História do Atlântico.

[64] Smith, L. (2006). Uses of heritage. Routledge.

[65] Sousa, A. (2015). Turismo e património museológicos: o caso dos museus do Funchal. Revista Turydes: Turismo y Desarrollo, 18. http://www.eumed.net/rev/turydes/18/ museus.html

[66] Sousa, J. J. A. de (1966). O movimento do porto do Funchal e a conjuntura da Madeira de 1727 a 1810 [Unpublished master's thesis]. University of Lisbon.

[67] Swarbrooke, J. (2015). Built attractions and sustainability. In C. M. Hall, S. Gössling, \& D. Scott (Eds.), The Routledge handbook of tourism and sustainability (pp. 356-364). Routledge.

[68] Walsh, K. (2002). The representation of the past: Museums and heritage in the post-modern world. Routledge.

[69] World Commission on Environment and Development. (1987). Our common future. Oxford University Press. 